\title{
Localization of neurones expressing the gap junction protein Connexin45 within the adult spinal dorsal horn: a study using Cx45-eGFP reporter mice
}

\author{
R. J. Chapman • V. K. Lall $\cdot$ S. Maxeiner • \\ K. Willecke $\cdot$ J. Deuchars $\cdot$ A. E. King
}

Received: 6 September 2011 / Accepted: 30 April 2012/Published online: 26 May 2012

(C) The Author(s) 2012. This article is published with open access at Springerlink.com

\begin{abstract}
Connexin $(\mathrm{Cx})$ proteins localized to neuronal and glial syncytia provide the ultrastructural components for intercellular communication via gap junctions. In this study, a Cx45 reporter mouse model in which the Cx45 coding sequence is substituted for enhanced green fluorescent protein (eGFP) was used to characterize $\mathrm{Cx} 45$ expressing neurones within adult mouse spinal cord. eGFP-immunoreactive (eGFP-IR) cells were localized at all rostro-caudal levels to laminae I-III of the dorsal horn (DH), areas associated with nociception. The neuronal rather than glial phenotype of these cells in DH was confirmed by co-localisation of eGFP-IR with the neuronal marker NeuN. Further immunohistochemical studies revealed that eGFP-IR interneurones co-express the calcium-binding protein calbindin, and to a lesser extent calretinin. In contrast, eGFP-IR profiles did not co-localize with either parvalbumin or GAD-67, both of which are linked to inhibitory interneurones. Staining with the primary afferent markers isolectin-B4 (IB4) and calcitonin gene-related peptide revealed that eGFP-IR somata within laminae I-III receive close appositions from the former, presumed non-peptidergic nociceptive afferents of peripheral origin. The presence of 5-HT terminals in close apposition to eGFP-IR interneuronal somata suggests modulation via descending pathways. These data demonstrate a highly localized expression of $\mathrm{Cx} 45$ in a population of interneurones within the mouse superficial dorsal horn. The implications of these data in the context of the putative role
\end{abstract}

R. J. Chapman · V. K. Lall · J. Deuchars $(\bowtie) \cdot$ A. E. King

Institute for Membrane and Systems Biology,

University of Leeds, Leeds LS2 9JT, UK

e-mail: j.deuchars@leeds.ac.uk

S. Maxeiner $\cdot$ K. Willecke

Institute of Genetics, University of Bonn, 53117 Bonn, Germany of Cx45 and gap junctions in spinal somatosensory processing and pain are discussed.

Keywords Immunohistochemistry · Dorsal horn · Connexin 45 . Gap junction · Nociception

$\begin{array}{ll}\text { Abbreviations } \\ \text { 5-HT } & \text { 5-Hydroxytryptamine } \\ \text { C } & \text { Cervical } \\ \text { CC } & \text { Central canal } \\ \text { CB } & \text { Calbindin } \\ \text { CBP } & \text { Calcium-binding proteins } \\ \text { CGRP } & \text { Calcitonin gene-related peptide } \\ \text { ChAT } & \text { Choline acetyltransferase } \\ \text { CR } & \text { Calretinin } \\ \text { Cx } & \text { Connexin } \\ \text { DH } & \text { Dorsal horn } \\ \text { EAP } & \text { Extra-avidin peroxidase } \\ \text { GAD-67 } & \text { Glutamic acid decarboxylase-67 } \\ \text { GFAP } & \text { Glial fibrillary-associated protein } \\ \text { eGFP } & \text { Enhanced green fluorescent protein } \\ \text { IR } & \text { Immunoreactive } \\ \text { ISH } & \text { In situ hybridisation } \\ \text { L } & \text { Lumbar } \\ \text { NeuN } & \text { Neuronal nuclei } \\ \text { NK }{ }_{1} \text { R } & \text { Neurokinin 1 receptor } \\ \text { nNOS } & \text { Neuronal nitric oxide synthase } \\ \text { OT } & \text { Oxytocin } \\ \text { PBS } & \text { Phosphate-buffered saline } \\ \text { PFA } & \text { Paraformaldehyde } \\ \text { PGK } & \text { Phosphoglycerine kinase } \\ \text { PKC } \gamma & \text { Protein kinase C gamma } \\ \text { PV } & \text { Parvalbumin } \\ \text { RTN } & \text { Reticular thalamic nucleus } \\ \text { TH } & \text { Tyrosine hydroxylase } \\ & \end{array}$




\section{Introduction}

In the adult mammalian central nervous system (CNS) gap junctions provide for rapid metabolic and electrical intercellular communication between neurones and glia (Nagy and Rash 2000). Gap junctions are composed of two hemichannels expressing homotypic, heterotypic or heteromeric combinations of specific connexin $(\mathrm{Cx})$ subunit proteins that influence channel conductance and kinetics (Sohl and Willecke 2003). Profiling studies in brain indicate that $\mathrm{Cx}$ subtypes are differentially localized to glia and neurones thus $\mathrm{Cx} 36$ and $\mathrm{Cx} 45$ are unambiguously present in neurones (Condorelli et al. 1998; Maxeiner et al. 2003; Hombach et al. 2004) whereas $C x 43$ and $C x 30$ are widely present in astrocytes (Theis et al. 2005). The concept of functional compartmentalization has emerged whereby the expression pattern of $\mathrm{Cx}$ proteins defines the strength of coupling between different cell types, thereby establishing a neuronglial syncytium that supports behaviours such as synchronized firing or propagation of calcium waves across disparate neuronal populations (Dermietzel 1998). Understanding the identity and expression patterns of Cx proteins is therefore a prerequisite to study the functional significance of gap junctions in the mature CNS.

Few studies have described in detail the distribution of gap junctions in adult rat spinal cord, but freeze-fracture studies revealed an abundance of mixed electrical/chemical synapses distributed across the grey matter of laminae III-IX (Rash et al. 1996). Regarding specific Cx subtypes, spinal cord expression profiles to date parallel those reported for brain. Thus, neuronal gap junctions contain Cx36 (Rash et al. 2000) or Cx47 (Teubner et al. 2001), whilst $\mathrm{C} \times 32$ and $\mathrm{Cx} 43$ are associated principally with oligodendrocytes and astrocytes, respectively (Rash et al. 2000; Nagy and Rash 2000; Ochalski et al. 1997). More recently, the use of $L a c \mathrm{Z}$ reporter gene expression or targeted $\mathrm{Cx} 45$ gene deletion in mice has revealed a strong association of this $\mathrm{Cx}$ subtype with neurones that express the protein marker NeuN (Sohl et al. 2005). Cx45 is highly expressed in brain during embryogenesis and after birth, thereafter levels decline such that $\mathrm{Cx} 45$ is more restricted, e.g. to thalamus or hippocampal CA3 region and different cortical layers (Maxeiner et al. 2003). To our knowledge, a full characterisation of the distribution of any of the neuronal $\mathrm{Cx}$ subtypes, including $\mathrm{Cx} 45$, throughout the murine spinal cord has not been performed. Determining the identity and distribution of the connexins in the dorsal horn is of interest because recent data imply a role for gap junctions localized to neurones or glia in rhythmic activity manifest in rat dorsal horn circuitry in vitro (Asghar et al. 2005; Chapman et al. 2009) and gap junctions are implicated in pain facilitation and inflammation-induced nociceptive behaviours (Lan et al. 2007; Qin et al. 2006).
Determining the distribution of Cx proteins in the CNS using traditional approaches of in situ hybridisation and immunohistochemistry has provided variable results and connexin-specific protocols required for both methods are not readily amenable to dual labelling (Sohl et al. 2005). As an alternative strategy, we have used a previously characterized transgenic mouse mutant line that expresses green fluorescent protein (GFP) in place of the $C x 45$ coding sequence (Maxeiner et al. 2005) to reveal a discretely localized population of $\mathrm{Cx} 45$ expressing cells within the superficial layers of the spinal dorsal horn. Immunohistochemistry was used to define the phenotype of neurones expressing $\mathrm{Cx} 45$ and determine putative sources of extrinsic innervation. The concentrated expression of these cells within laminae I-III places them in a strategic position to potentially influence the processing of somatosensory afferent inputs, particularly those arising from nociceptors.

\section{Materials and methods}

\section{Animals}

All procedures were carried out in accordance with the UK Animals (Scientific Procedures) Act of 1986 and experimental protocols were approved by the local Faculty of Biological Sciences Ethics Committee. All experiments utilized mice with a cell-directed deletion of $\mathrm{Cx} 45$ and a concomitant activation of GFP (Theis et al. 2000), the constructs of which have been outlined previously in detail (Maxeiner et al. 2005). In summary, to allow for conditional deletion of the $\mathrm{Cx} 45$ coding region on exon 3 of the $\mathrm{Cx} 45$ gene, exon3 was flanked by two loxP sites in intron2 and downstream of exon3, respectively. Upstream of the $5^{\prime}$ prime loxP site, a frt sites flanked minigene harbouring the neomycin resistance gene under the regulatory elements of the phosphoglycerate kinase promoter (PGK-neo) has been inserted to identify positive clones during ES-cell culture. Downstream of the second loxP site, the immediate upstream intronic sequence of the $\mathrm{Cx} 45$ gene has been duplicated and the endogenous Kozak consensus motif has been fused to the enhanced green fluorescent protein (eGFP) coding DNA. Eventually, Cre-recombinase expression under control of the nestin promoter will lead to the recombination of both loxP sites and delete the $\mathrm{Cx} 45$ coding DNA by replacing it with eGFP, restricting eGFP expression primarily to neurones as described previously (Maxeiner et al. 2005). To avoid putative disturbances in the expression of Cx45/eGFP by constitutive expression of the neomycin resistance gene, all mice analysed were devoid of PGK-neo minigene accomplished by previous breedings to Flp-recombinase expressing mice. 


\section{Cx45-eGFP immunohistochemistry}

Adult mice $(n=6)$ were anaesthetised with pentobarbitone $(60 \mathrm{mg} / \mathrm{kg}$, i.p.) and transcardially perfused with fixative containing $4 \%$ paraformaldehyde (PFA; in $0.1 \mathrm{M}$ phosphate buffer, $\mathrm{pH}$ 7.4). The spinal cords were removed and post-fixed in $4 \%$ PFA overnight at $4{ }^{\circ} \mathrm{C}$. Transverse sections $(50 \mu \mathrm{m})$ cut from the middle of the cervical, thoracic, lumbar and sacral regions were cut on a vibrating microtome (Leica, Milton Keynes, UK) and collected into phosphate-buffered saline (PBS; $\mathrm{pH} 7.2$ ). Sections were permeabilised by the inclusion of $0.1 \%$ Triton $\mathrm{X}-100$ (Sigma, UK) in the primary antibody solution to GFP, washed in PBS $(3 \times 10 \mathrm{~min})$ and transferred to either chicken or rabbit anti-GFP primary antibodies $(1: 1,000$, Invitrogen) for $12-36 \mathrm{~h}\left(4^{\circ} \mathrm{C}\right)$. Prior to secondary antibody application, all sections were washed in PBS $(3 \times 10 \mathrm{~min})$. Anti-GFP was visualised using Alexa ${ }^{488}$-conjugated donkey anti-chicken or rabbit (1:1,000, Invitrogen). Secondary antibodies were applied for $2-3 \mathrm{~h}\left(4^{\circ} \mathrm{C}\right)$ and sections washed in PBS before drying, mounting and cover slipping using Vectashield (Vector Laboratories, Peterborough, UK). As a procedural control, the primary antibodies were replaced by $\mathrm{PBS}$ to ensure that the antiserum detected the appropriate antigen and under these conditions no staining occurred. Low- and high-power images were captured using a Nikon (Surrey, UK) Eclipse E600 epifluorescence microscope and AcQuis image capture software (Synoptics, Cambridge, UK). Corel Draw 13 was used to adjust brightness, contrast, intensity and gamma, if appropriate. Some images (Fig. 3) were inverted to aid visualisation of co-localisation in black and white images.

Double immunolabelling protocol

Following incubation in anti-GFP antibodies and Alexa ${ }^{488}$ conjugated secondary antibodies as described above, spinal cord lumbar sections were washed in PBS $(3 \times 10 \mathrm{~min})$ and incubated in primary antibodies (in PBS/0.1\% Triton $\mathrm{X}-100)$ for $12-36 \mathrm{~h}\left(4{ }^{\circ} \mathrm{C}\right)$. Sections were washed in PBS $(3 \times 10 \mathrm{~min})$ prior to secondary antibody application. Anti-GFP was visualised using Alexa ${ }^{488}$-conjugated donkey anti-chicken or rabbit (1:1,000, Invitrogen) and all other antigens were individually visualised using Alexa ${ }^{555}$ conjugated to the appropriate species for $2-3 \mathrm{~h}\left(4^{\circ} \mathrm{C}\right)$. Biotinylated IB4 (1:100) was visualised by incubating sections for $1 \mathrm{~h}$ in Streptavidin Alexa ${ }^{55}$ (1:100, Invitrogen). Staining for glutamate decarboxylase (GAD)-67 involved section pre-treatment by incubating in $50 \%$ ethanol (30 min) and then in $10 \%$ donkey serum (30 min), but with the avoidance of triton following the protocol of Fong et al. (2005) who noted that detergent decreased GAD-67 labelling in somata in the brainstem. Thereafter, sections were incubated in primary antibody for $12-36 \mathrm{~h}$ $\left(4{ }^{\circ} \mathrm{C}\right)$. GAD-67 was visualised using a two-stage process: (1) sections were incubated in biotin anti-mouse (1:200, Vector Laboratories) for $4 \mathrm{~h}\left(4^{\circ} \mathrm{C}\right)$, washed $(3 \times 10 \mathrm{~min})$ and incubated in ExtrAvidin peroxidase (EAP; 1:1,500, Sigma) for $12 \mathrm{~h}\left(4^{\circ} \mathrm{C}\right)$; (2) following removal from EAP, sections were washed $(3 \times 10 \mathrm{~min}$ each $)$ and amplified using a tyramide signal amplification (TSA) kit (Coumarin-tyramide solution (1:100 PBS) plus $1 \%$ hydrogen peroxide solution (Perkin Elmer LAS Inc., USA). Finally, sections were washed in PBS $(3 \times 10 \mathrm{~min})$, air-dried, mounted and cover slipped using Vectashield for viewing with a Nikon E600 image capture system equipped with epifluorescence.

\section{Immunohistochemistry for $\mathrm{Cx} 45$}

2-month-old wild type mice (C57/BL6) were anaesthetised with intraperitoneal pentobarbital solution $(50 \mathrm{mg} / \mathrm{Kg})$ and transcardially perfused with $0.1 \mathrm{M}$ PBS, $\mathrm{pH} 7.4$ followed with $2 \%$ PFA and $0.2 \%$ picric acid in $0.1 \mathrm{M}$ phosphate buffer (PB), pH 7.4 for 15 min. Spinal cords were sectioned at $30-50 \mu \mathrm{m}$ as above. Sections were treated with pepsin $(0.2 \mathrm{mg} / \mathrm{ml})$ in $2 \mathrm{M} \mathrm{HCL}$ at $37{ }^{\circ} \mathrm{C}$ for $10 \mathrm{~min}$ followed by 3-, 10-min washes in PB (Vervaeke et al. 2010). Sections were then permeabilised with the inclusion of $3 \%$ Triton X-100 (Sigma) in the primary antibody solution; polyclonal rabbit anti-Cx45 (1:250, Invitrogen, cat 40-7000) for $36 \mathrm{~h}$ at $4{ }^{\circ} \mathrm{C}$ before visualisation with Alexa ${ }^{555}$ conjugated donkey anti-rabbit (1:1,000, Invitrogen) as above. As a procedural control, the primary antibodies were replaced by PBS to ensure that the antiserum detected the appropriate antigen and under these conditions no staining occurred.

Antibody characterisation

\section{Calbindin $(C B)$}

Mouse anti-CB D-28k monoclonal antibody (Swant, Switzerland; code no. 300, lot no. 07(F); form, lyophilised concentrated supernatant with no preservatives, used at 1:5,000) was produced by hybridization of mouse myeloma cells with spleen cells from mice immunized with $\mathrm{CB}$ purified from chicken gut. The staining observed with this antibody gave an identical staining pattern in the mouse spinal cord compared with previous investigations using an antibody from a different origin (Ruda et al. 1994) and did not stain the brain of CB knockout mice (Swant Data sheet).

\section{Calcitonin gene-related peptide (CGRP)}

Chicken anti-CGRP antibody was raised against the synthetic peptide sequence KDNFVPTNVGSEAF-NH2 
(Neuromics, code no. CH14100, used at 1:200). Staining of spinal cord sections revealed patterns previously documented with this antibody (Gao et al. 2009) and is identical to immunoreactivity observed with different antibodies to CGRP (Neumann et al. 2008).

\section{Choline acetyltransferase (ChAT)}

Polyclonal goat anti-ChAT antibody was produced from human placental enzyme (Millipore, code no. AB144P, used at 1:500). Immunoblot analysis has identified antibody specificity in cholinergic neurones in the CNS in a variety of species (Millipore data sheet) and stains brainstem and spinal cholinergic neurones in well established patterns (Milligan et al. 2006).

\section{Calretinin (CR)}

Rabbit anti-CR polyclonal antibody (Swant, Switzerland; code no. 7699/3H, lot no. 18299; form, lyophilised antiserum, used at 1:5,000) was produced against human recombinant CR. Antibody specificity was evaluated by Biotin-Avidin labelling of fixed brain preparations and by immunoenzymatic labelling of immunoblots (Swant data sheet; Schwaller et al. 1993) and does not stain the brain of CR knockout mice (Swant data sheet).

\section{Cx45}

Rabbit anti-Cx45 is raised against a synthetic peptide corresponding to the c-terminal region of protein (Invitrogen code no. 40-7000, used at 1:250). The manufacturer indicates that it specifically detects Cx45 in mouse brain homogenates in western blots and stains expected cell types in retina and mouse brain. Staining was comparable to expression as indicated in Fig. 1 in this study.

\section{GAD-67}

Mouse anti-GAD67 monoclonal antibody (Chemicon, MAB5406; Clone 1G10.2, used at 1:1,000) was produced against recombinant GAD-67 fusion protein. The GAD-67 antibody reacts with the $67 \mathrm{kDa}$ isoform of GAD-67 of rat, mouse, and human origins, and there is no detectable cross reactivity with GAD-65 by western blotting of rat brain lysate (Chemicon data sheet for MAB5406; Fong et al. 2005).

\section{Glial fibrillary acidic protein (GFAP)}

Mouse monoclonal anti-GFAP antibody was produced by hybridisation of $\mathrm{Sp} 2 / 0$ myeloma cells with splenocytes from Balb/c mice immunised with purified human GFAP
(Biomol, code no. BML-GA1170; clone EB4). The antibody recognises GFAP in a wide range of species (Biomol data sheet) and staining displays classic morphology and distribution of fibrillary astrocytes.

\section{GFP}

According to the manufacturer, both rabbit (Invitrogen, A11122) and chicken (Invitrogen, A10262) anti-GFP antibodies are suited for detection of native GFP, GFP variants, and GFP fusion proteins by western blot and immunohistochemistry analysis using transgenic mice expressing the GFP gene product. Labelling was only detected in cells that expressed GFP and no staining was observed in sections derived from wild-type mice.

\section{5-Hydroxytryptamine (5-HT)}

Rabbit polyclonal anti-5-HT antibody was raised against 5-HT coupled to bovine serum albumin with PFA (used at dilution of 1:1,000). The pattern of staining observed matches that observed with other 5-HT antibodies in spinal cord terminals and brainstem raphe neurones (Izzo et al. 1993).

\section{IB4}

Isolectin GS-IB4 from Griffonia simplicifolia conjugated to Alexa $^{568}$ (Invitrogen, I21412) was used (1:100) to label non-peptidergic nociceptive afferents (Snider and McMahon 1998).

\section{Mu opioid receptor (MOR)}

Monoclonal rabbit anti-MOR antibody was raised against a synthetic peptide corresponding to residues on the human MOR (Abcam, code no. AB51140, diluted to 1,000). The MOR antibody recognised a single band of approximately $52 \mathrm{kDa}$ on immunoblots from human brain lysate (Abcam data sheet). Staining was comparable to that observed using different antibodies to the receptor (Arvidsson et al. 1995).

\section{Neuronal nuclei (NeuN)}

Monoclonal mouse anti-NeuN (used at 1:1,000) was raised against purified cell nuclei from mouse brain (Chemicon, code no. MAB377; Clone A60). Immunohistochemistry and immunoblots in a variety of CNS tissues revealed detectable antigen only in nerve cells (Mullen et al. 1992). The immunohistochemical staining is primarily localized to the nucleus of the neurones, with lighter staining in proliferative zones (Mullen et al. 1992). The few cell types 
Fig. 1 Regional expression of Cx45-eGFP is consistent with in situ hybridisation, reporter expression in another transgenic mouse line and protein localisation. a, c, f eGFP-IR from the Cx45-eGFP mouse. $\mathbf{b}, \mathbf{d}$ In situ hybridisation images for $\mathrm{Cx} 45$, taken from the Allen Brain Atlas. e, $\mathbf{g}$ Images of expression in a $\mathrm{Cx} 45 \mathrm{BAC}$ reporter mouse taken from the Gensat project. High levels of expression are evident in neurones in the thalamus $(\mathbf{a}, \mathbf{b})$, ependymal cells surrounding the spinal cord central canal (c-e) and in layers I-III in the dorsal horn (f, $\mathbf{g})$. Closed head arrows indicate neurones whilst open head arrows blood vessels apparent due to smooth muscle labelling. Immunoreactivity for Cx45 can also be detected in the ependymal cell layer (h), dorsal horn (i) and in blood vessels (j). $\mathbf{b}, \mathbf{e}, \mathbf{g}$ Inverted from original images to correspond with those shown here. $r t n$ reticular thalamic nucleus. Colour images are available online
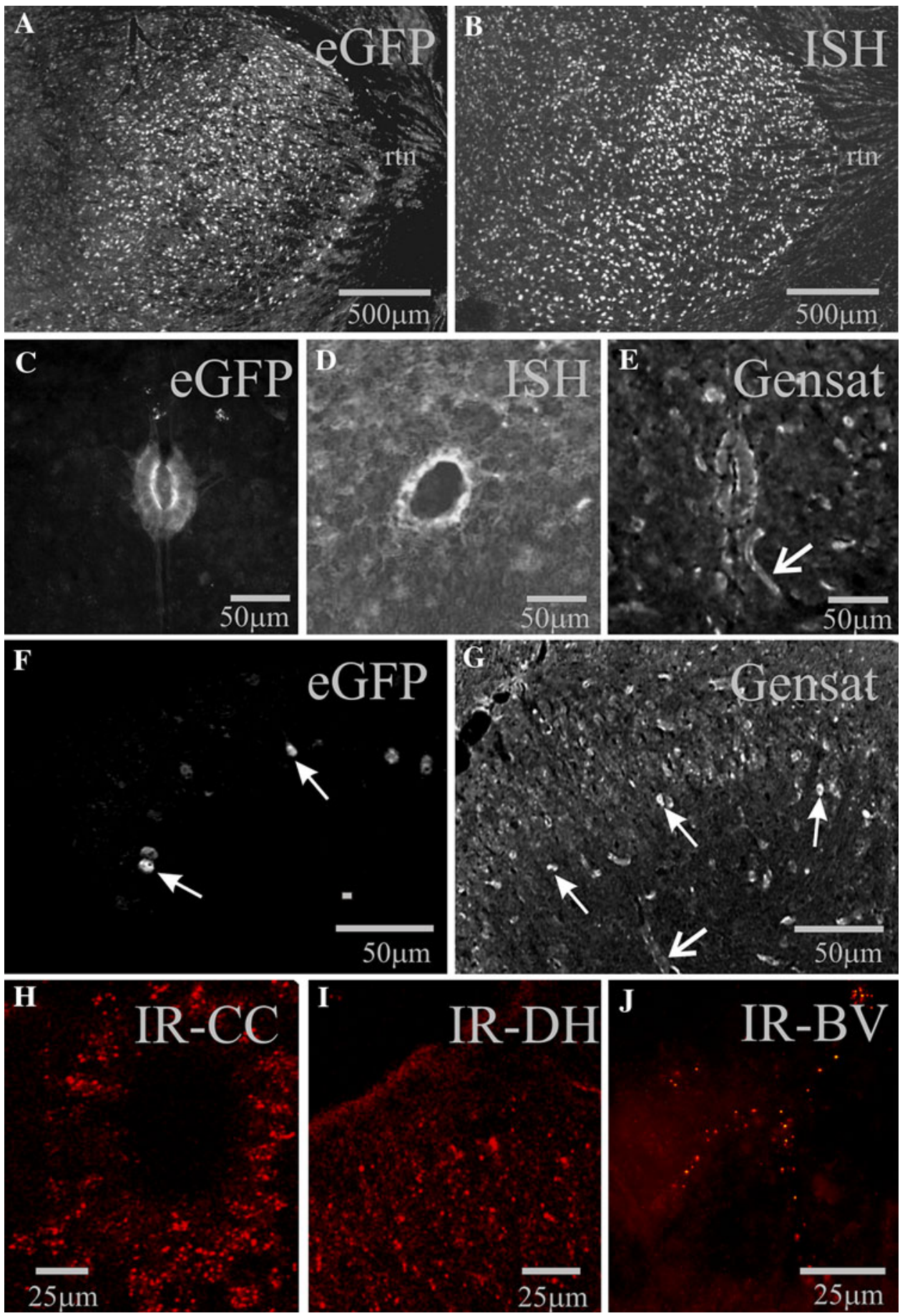

not reactive with MAB377 include Purkinje, mitral and photoreceptor cells.

\section{Neurokinin-1-receptor $\left(N K_{1} R\right)$}

Polyclonal guinea pig anti- $\mathrm{NK}_{1} \mathrm{R}$ antibody was raised against a synthetic peptide corresponding to the C-terminal sequence (KTMTESSSFYSNMLA; amino acid residues 393-407) of the $\mathrm{NK}_{1} \mathrm{R}$ (Biomol, code no. BML-NA4200, used at 1:500). This antibody has been characterised extensively in rat (Vigna et al. 1994).

Nitric oxide synthase ( $\mathrm{NNOS)}$

Polyclonal rabbit anti-nNOS was raised against a synthetic peptide corresponding to aa1414-1434 of human brain NOS (NOS1; Biomol, code no. BML-SA227-0025, used at $1: 1,000)$. This antibody specifically recognizes human, 
mouse and rat nNOS (Biomol data sheet). Antibody staining in mouse spinal cord reveals identical patterns to those previously documented (Maihofner et al. 2000; Ma and Eisenach 2007).

\section{Oxytocin (OT)}

Polyclonal rabbit anti-OT was raised against the amino acid sequence CYIQNCPLG, corresponding to N-terminal amino acids 20-28 of OT (Abcam, code no. AB11143, used at 1:10,000). According to the manufacturer this antibody blocks completely with OT peptide. Staining with this antibody revealed a similar pattern of distribution to previous investigations in the mouse spinal cord and a lack of staining was observed in knockout mice lacking OT (Robinson et al. 2002).

\section{Protein kinase $C(P K C) \gamma$}

Polyclonal rabbit anti-PKC $\gamma$ was raised against a peptide mapping the c-terminus of $\mathrm{PKC} \gamma$ of mouse origin (Santa Cruz Biotech, sc-211, used at 1:1,000). Staining with this antibody gave an identical pattern of distribution in the mouse spinal cord to previous reports (Malmberg et al. 1997).

\section{Parvalbumin $(P V)$}

Monoclonal mouse anti-PV was produced by hybridization of mouse myeloma cells with spleen cells taken from mice immunized with PV purified from carp muscles (Swant, Switzerland; code no. 235, lot no. 10-11(F); form, lyophilised ascites, used at 1:5,000). Antibody specificity was evaluated by immunoenzymatic labelling of immunoblots and radioimmunoassay (Swant data sheet); (Celio et al. 1988). Additionally, immunolabelling using this antibody is absent in PV knockout mice (Schwaller et al. 1999).

\section{Tyrosine hydroxylase (TH)}

Polyclonal sheep anti-TH was raised against native rat $\mathrm{TH}$ purified from pheochromocytoma (Novus Biologicals, code no. NB300-110; Clone LNC1, used at 1:1,000). Staining with this antibody was identical to that observed in mouse spinal cord using an antibody from a different origin (Brumovsky et al. 2006).

\section{Confocal microscopy and 3D reconstruction}

Mounted sections were viewed on a confocal laser scanning fluorescence microscope equipped with both argon $\left(\lambda_{\mathrm{ex}}=488 \mathrm{~nm}\right)$ and $\mathrm{He}-\mathrm{Ne}\left(\lambda_{\mathrm{ex}}=543 \mathrm{~nm}\right)$ lasers that are able to visualize optical sections through a $40 \times$ Fluor oil immersion objective (numerical aperture 1.3). Confocal images were captured as single slices or stacks and images analysed using Reconstruct ${ }^{\mathrm{TM}}$ software (Fiala 2005). Serial images were imported into Reconstruct ${ }^{\mathrm{TM}}$ and calibrated using a scale bar. A 3D model of Cx45-eGFP cell bodies could be generated by outlining the area of the cell somata within each serial section image. Only close appositions to Cx45-eGFP cell bodies were quantified since there is only sparse dendritic staining for eGFP. To be considered as a close apposition, the labelled presynaptic fibre was required to be directly adjacent to the GFP neurone in the same plane of focus, determined through confocal microscopy and rotation of Z-stack images of apparent contact point.

Data and statistical analyses

Cell counts were calculated from the whole dorsal horn region of 10 representative sections from a minimum of 3 animals and contact density of potential terminal appositions were calculated from a minimum of 15 whole cells from each animal. Data are expressed as mean \pm SEM where $N$ represents the total number of cells and $n$ represents the number of animals.

\section{Results}

Regional Cx45-eGFP expression in the CNS correlates to in situ hybridisation

To determine if regional expression of eGFP in the Cx45 mice was consistent with $\mathrm{Cx} 45$ gene expression, we compared eGFP immunohistochemistry with expression reported by the Allen Brain Atlas (http://www.brain-map. org/) in the brain (Image Series ID:77887876) as well as the spinal cord (Image series ID $=100009459$ ). The expression studies reveal highest levels in the brain in the thalamic relay nuclei, whilst the reticular thalamic nucleus is devoid of labelling (Fig. 1b). This pattern is repeated in Cx45-eGFP mice, where eGFP immunoreactivity is strong in thalamic relay neurones but absent from the reticular nucleus (Fig. 1a). In the spinal cord $\mathrm{Cx} 45$-eGFP was apparent in the ependymal cells lining the central canal (Fig. 1c) and this is paralleled by the expression levels detected Allen Brain Atlas spinal cord (Fig. 1d). We further compared expression in this transgenic mouse to that observed in a reporter mouse made by the Gensat project (Gensat 2011) using a BAC vector to control expression of Cx45 (http://www.gensat.org/imagenavigator.jsp?imageID $=80609$ ). Expression was comparable, localised predominantly to the ependymal layer of the central canal (Fig. 1e) and the dorsal horn (Fig. 1f, g). In addition, the Gensat 
mouse revealed the expected labelling of blood vessel smooth muscle (Fig. 1e, g). This is not observed in the eGFP mouse as the deletion of $\mathrm{Cx} 45$ and hence expression of GFP is directed only to neurones since eGFP-positive cells co-labelled with NeuN but not GFAP (see below). We also compared expression with labelling for $\mathrm{Cx} 45$ protein and found concentrated immunoreactive spots, presumably gap junction proteins, in the ependymal cell layer (Fig. 1h), dorsal horn (Fig. 1i) and in blood vessels (Fig. 1j). Thus, the reporter expression pattern in neurones in the mouse used in this study was similar to that of another transgenic mouse, to expression revealed by in situ hybridisation and to the localisation of immunoreactivity.
Cx45-eGFP cells within the spinal cord dorsal horn are neuronal

In addition to the ependymal cell layer, GFP-immunohistochemistry to reveal the distribution of Cx45-eGFP in the spinal cord indicated a discrete localisation to laminae I-III of the dorsal horn (Fig. 2a). The highest concentration of Cx45-eGFP cells was in lamina II encompassing both the inner and outer layers. Cx45-eGFP cells were also observed in lamina III, with most cells located near the laminae II-III border. Fewer Cx45-eGFP cells were found scattered across lamina I. No Cx45-eGFP cells were observed in deeper laminae of the dorsal horn or within the
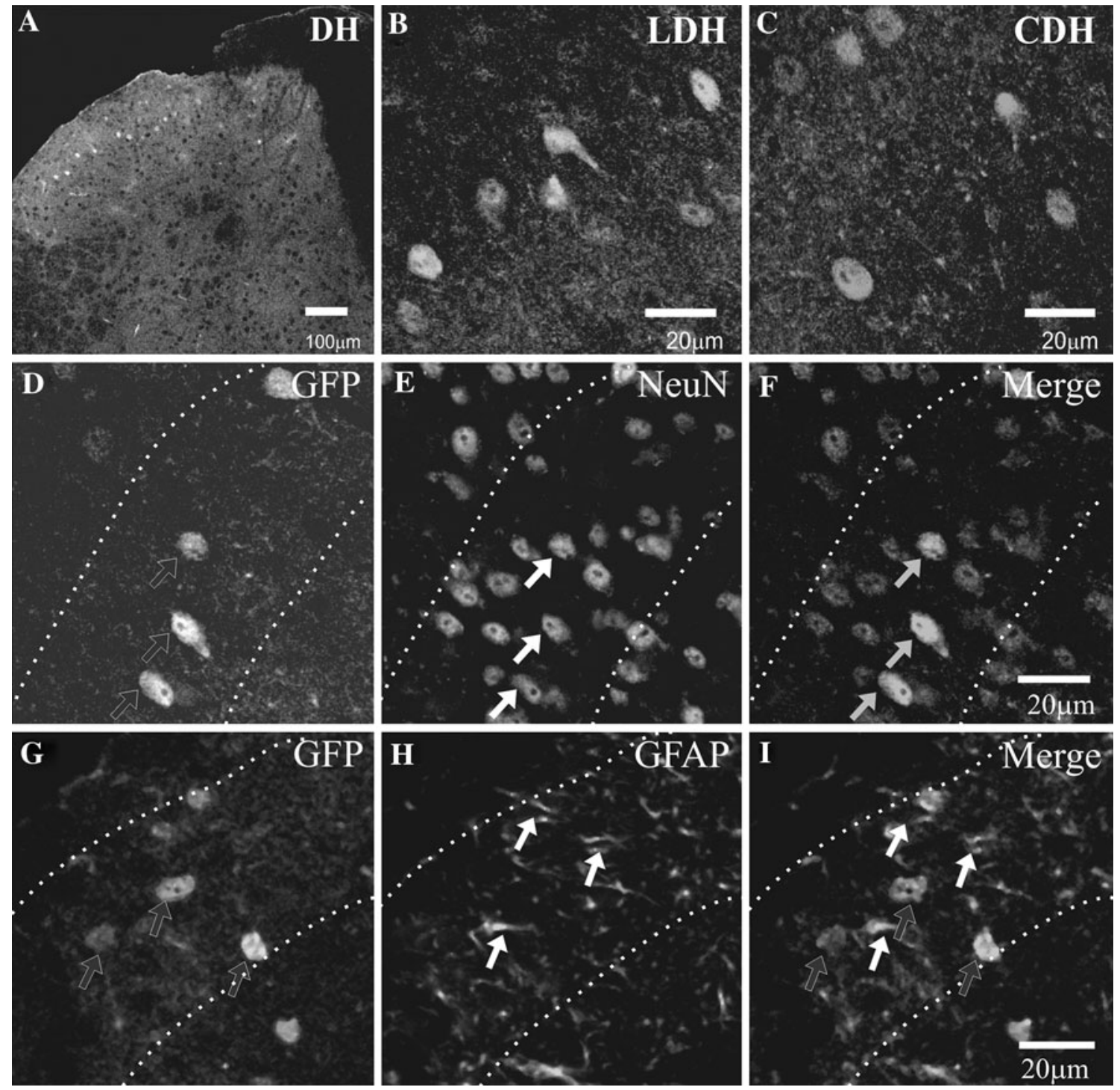

Fig. 2 Distribution of $\mathrm{Cx} 45$-eGFP cells is mainly concentrated within neurones localized to laminae I-III of the cervical, thoracic, lumbar and sacral DH. a Confocal scan of the lumbar spinal DH showing a discrete band of GFP-IR cells lying predominantly within laminae II-III. High power magnification of $\mathrm{Cx} 45$-eGFP cells present in the lumbar $\mathrm{DH}(\mathrm{LDH} ; \mathbf{b})$ and cervical $\mathrm{DH}(\mathrm{CDH} ; \mathbf{c})$. $\mathbf{d}-\mathbf{i}$ Confocal tiled scan shows Cx45-eGFP cells co-localize with the neuronal marker NeuN (f) but not with the glial marker GFAP (i) within laminae I-III. Cx45-eGFP cells, black arrows with white borders; NeuN and GFAP, white arrows. The third tile of each row shows a merged representation; GFP-IR in cells was co-localized with NeuN, grey arrows. Dashed lines represent the borders of lamina II 
ventral horn. Abundant Cx45-eGFP-immunoreactive (eGFP-IR) could be found within the lumbar (Fig. 2b) and thoracic regions of the spinal cord, although numerous Cx45-eGFP cells were observed at all rostro-caudal levels including cervical (Fig. 2c) and sacral regions. 3D reconstruction of $90 \mathrm{Cx} 45$-eGFP cells revealed a mean somatic surface area of $45.9 \pm 7.5 \mu^{2}(n=6)$. Dual-immunolabelling of Cx45-eGFP with either NeuN or GFAP revealed a strong association with the former. Whilst the number of NeuN-IR cells was significantly higher than that of $\mathrm{Cx} 45-$ eGFP cells, all eGFP-IR was co-localized with NeuN within laminae I-III ( $n=3$; Fig. $2 d-f)$. In contrast to this, whilst GFAP itself was abundantly expressed within spinal grey matter, there was no apparent co-localisation with Cx45-eGFP-IR profiles ( $n=3$; Fig. $2 \mathrm{~g}-\mathrm{i}$ ).

\section{Cx45-eGFP cells contain calcium-binding proteins}

To probe further the phenotype of the Cx45-eGFP cells, we performed dual immunolabelling of GFP with the calciumbinding proteins (CBPs), $\mathrm{CB}, \mathrm{CR}$ and $\mathrm{PV}$ as well as the GABAergic marker GAD-67. All of the antigens investigated revealed a wide distribution of cells containing $\mathrm{CB}$, CR, PV and GAD-67 throughout the dorsal horn and in significantly higher numbers than Cx45-eGFP cells (Fig. 3), in accordance with those published in the atlas of the mouse spinal cord (Watson et al. 2009). Immunoreactivity for the CBPs could be found throughout the spinal cord, with a higher percentage of ventral horn neurones staining for PV than $\mathrm{CB}$ or CR. In the dorsal horn, pronounced $\mathrm{CB}$ and $\mathrm{CR}$ immunoreactivity was observed within laminae I-II (Fig. 3b, e), whilst PV (Fig. 3h) intensely stains the inner part of lamina II. Of the Cx45eGFP cells observed within laminae I-III (Fig. 3a, d, g, j), $93.5 \pm 0.6 \%$ were immunoreactive for $\mathrm{CB}$ (mean number of cells taken from 10 sections: $17 \pm 1$ GFP cells, and $16 \pm 1 \mathrm{CB}$ containing cells; $N=405$ of 433, $n=3$; Fig. 3c) and, to a lesser extent, $26.76 \pm 1.2 \%$ were immunoreactive for CR (mean number of cells from 10 sections: $19 \pm 1$ GFP cells, and $7 \pm 1$ CR containing cells; $N=110$ of $411, n=3$; Fig. 3f). PV or GAD-67 containing cells were distinct from Cx45-eGFP cells at all levels of the dorsal horn $(n=3$, Fig. $3 \mathrm{i}, 1)$.

Cx45-eGFP cells are putatively innervated by non-peptidergic sensory afferents and descending monoaminergic fibres

To determine putative sources of afferent innervation for Cx45-eGFP cells, immunolabelling for both IB4 (a nonpeptidergic fibre marker) and CGRP (a peptidergic fibre marker) was performed. Cx45-eGFP cells within laminae I-II (Fig. 4a, c) were surrounded by IB4-positive fibres and those in lamina III received close appositions from IB4positive fibres (Fig. 4b, d, e). 3D reconstructed models permitted measurements of putative contact density of IB4positive fibres onto Cx45-eGFP cell somata (Fig. 4f, g). From 45 Cx45-eGFP cells analysed, the average putative contact density was calculated as $23.6 \pm 2.4$ appositions per $100 \mu^{2}$. Immunolabelling for CGRP revealed widespread projections of presumed peptidergic sensory neurones predominantly within lamina I and the outer layer of lamina II (Fig. 4i). However, in contrast to IB4, Cx45eGFP cells were devoid of CGRP-positive close appositions (Fig. 4j).

Another major extrinsic source of innervation to the dorsal horn is via descending 5-HT pathways. Labelling for this monoamine was widespread throughout the dorsal horn (Fig. 5b, e) and, more specifically, within laminae I-II in the region of Cx45-eGFP cells. 5-HT terminals made close appositions to $\mathrm{Cx} 45$-eGFP cell somata (Fig. 5c, f). Using $3 \mathrm{D}$ reconstructed models from $45 \mathrm{Cx} 45$-eGFP cells, the contact density of putative 5-HT terminals onto $\mathrm{Cx} 45$ eGFP somata was calculated as $15.8 \pm 1.92$ appositions per $100 \mu \mathrm{m}^{2}$ ( $n=3$; Fig. $5 \mathrm{~g}-\mathrm{i}$ ).

Immunolabelling for either OT or $\mathrm{TH}$ confirmed their presence in mouse dorsal horn. Both OT and TH fibres displayed a widespread distribution within the dorsal horn, terminating within laminae I and II and some OT fibres were found in lamina $\mathrm{X}$. However, no clear association with Cx45-eGFP cells was established in this study.

Cx45-eGFP-IR cells do not contain nNOS, ChAT, $\mathrm{NK}_{1} \mathrm{R}, \mathrm{MOR}$ and $\mathrm{PKC} \gamma$

To characterise the Cx45-eGFP-IR cells further, double immunolabelling was performed with other cell markers for identified dorsal horn populations such as nNOS, ChAT, $\mathrm{NK}_{1} \mathrm{R}, \mathrm{MOR}$ and PKC $\gamma$ (data not shown). Cells immuno-positive for nNOS could be observed throughout the superficial and deep dorsal horn but these were not Cx45-eGFP-IR cells. ChAT-immunoreactivity could be observed within the deep dorsal horn and ventral horn, but did not overlap with $\mathrm{Cx} 45$-eGFP-IR. Numerous $\mathrm{NK}_{1} \mathrm{R}$ immunoreactive cells were observed within laminae I and III/IV, but those in lamina III did not co-localize with Cx45-eGFP-IR. The distribution of MOR and PKC $\gamma$ staining was mainly concentrated within the superficial dorsal horn and also did not overlap with Cx45-eGFP-IR.

\section{Discussion}

In this study, we have demonstrated using Cx45-eGFP transgenic mice that $\mathrm{Cx} 45$-eGFP cells are distributed along the rostrocaudal extent of the spinal cord with expression 

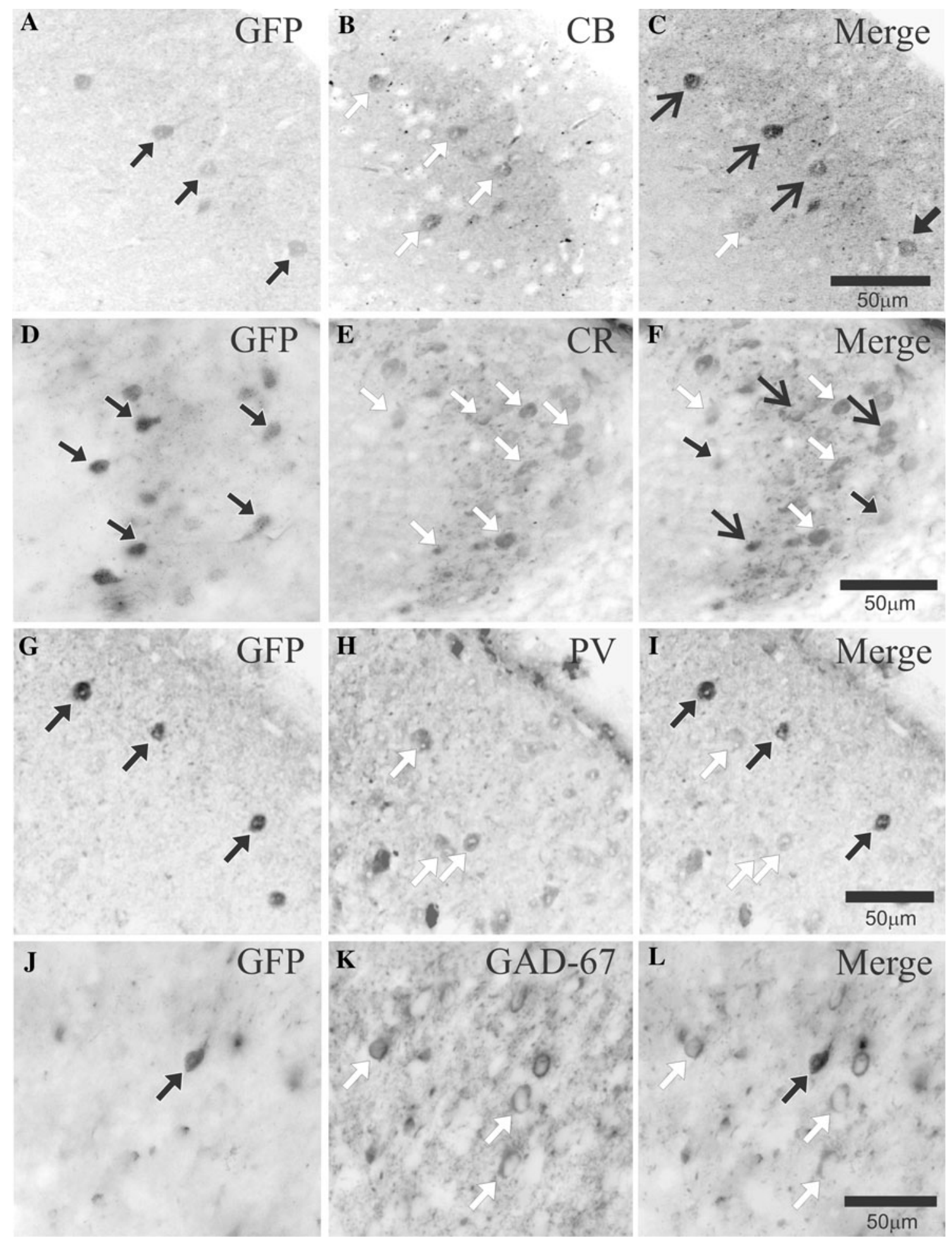

Fig. 3 Cx45-eGFP cells co-localize with the CBPs CB and CR. a-f Cx45-eGFP cells show co-localisation with CB (c) and CR (f). g-l No co-localisation is observed with PV, or with GAD-67. Cx45-

mainly restricted to the grey matter of dorsal laminae I-III. Cx45-eGFP cells were identified as neuronal on the basis of co-localisation with NeuN and confined to a population
eGFP cells, closed head black arrows; cells containing CB, CR, PV or GAD-67, white arrows; cells displaying co-localisation, open head black arrows

of interneurones that expressed $\mathrm{CB}$, and to a lesser extent, CR. No association was established between Cx45-eGFP cells and interneurones containing either PV or GAD-67. 

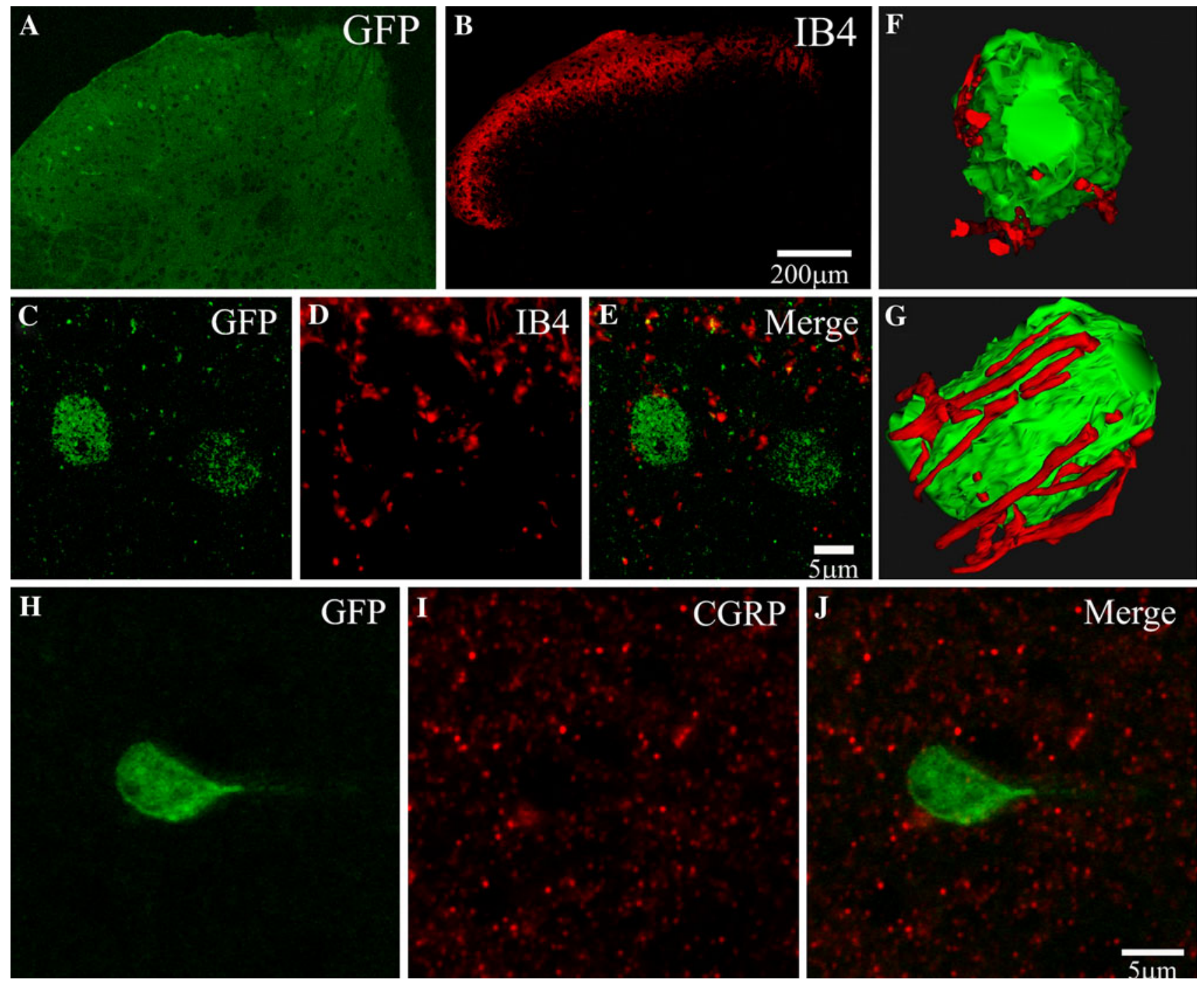

Fig. 4 a, b IB4 staining is clearly observed within laminae I/II of the $\mathrm{DH}$ and makes close appositions to both $\mathrm{Cx} 45$-eGFP cells within laminae I/II and those in lamina III. c-e Confocal scan of representative cells (from lamina III in a) demonstrate the density of projections surrounding the Cx45-eGFP cells. f, $\mathbf{g}$ A reconstructed

However, Cx45-eGFP somata were in close apposition to IB4-positive fibres implying a non-peptidergic nociceptive afferent source of peripheral innervation (Snider and McMahon 1998). In addition, Cx45-eGFP cells were in close proximity to 5-HT-containing fibres and may therefore receive some level of monoaminergic descending neuromodulatory input.

\section{Technical considerations- the Cx45-eGFP reporter} mouse model

Localisation of $\mathrm{Cx} 45$ protein has been difficult to obtain due to low levels of $\mathrm{Cx} 45$ protein and lack of specific antibodies, leading to the study of $\mathrm{Cx} 45$ expression using mouse models in which the $\mathrm{Cx} 45$ gene has been replaced model example in two orientations illustrating the density of projections onto the cell soma and putative sites of contact. $\mathbf{h}-\mathbf{j}$ Staining with CGRP demonstrates that Cx45-eGFP cells do not receive close appositions from CGRP-positive fibres. Colour images are shown online

by that for reporter molecules in the olivo-cerebellar system (Van Der Giessen et al. 2006) and the retina (Maxeiner et al. 2005; Schubert et al. 2005; Dedek et al. 2009). Indeed, cells that express $\mathrm{Cx} 45$ as shown by reporter molecules also reveal coupling in retinal neurones typical of gap junctions and this coupling is disrupted when $\mathrm{Cx} 45$ is deleted (Maxeiner et al. 2005; Dedek et al. 2009), their Fig. 4e), indicating that reporter expression correlates with Cx45 gap junction protein presence. Such correlation of eGFP expression with $\mathrm{Cx} 45$ in the reporter mouse in this study appears to continue in the brain and spinal cord with the observation that mRNA encoding $\mathrm{Cx} 45$ and eGFP are present in the thalamic relay neurones and spinal cord ependymal cells (Fig. 1). It cannot be guaranteed that $100 \%$ of cells that express $\mathrm{Cx} 45$ can be visualised with 

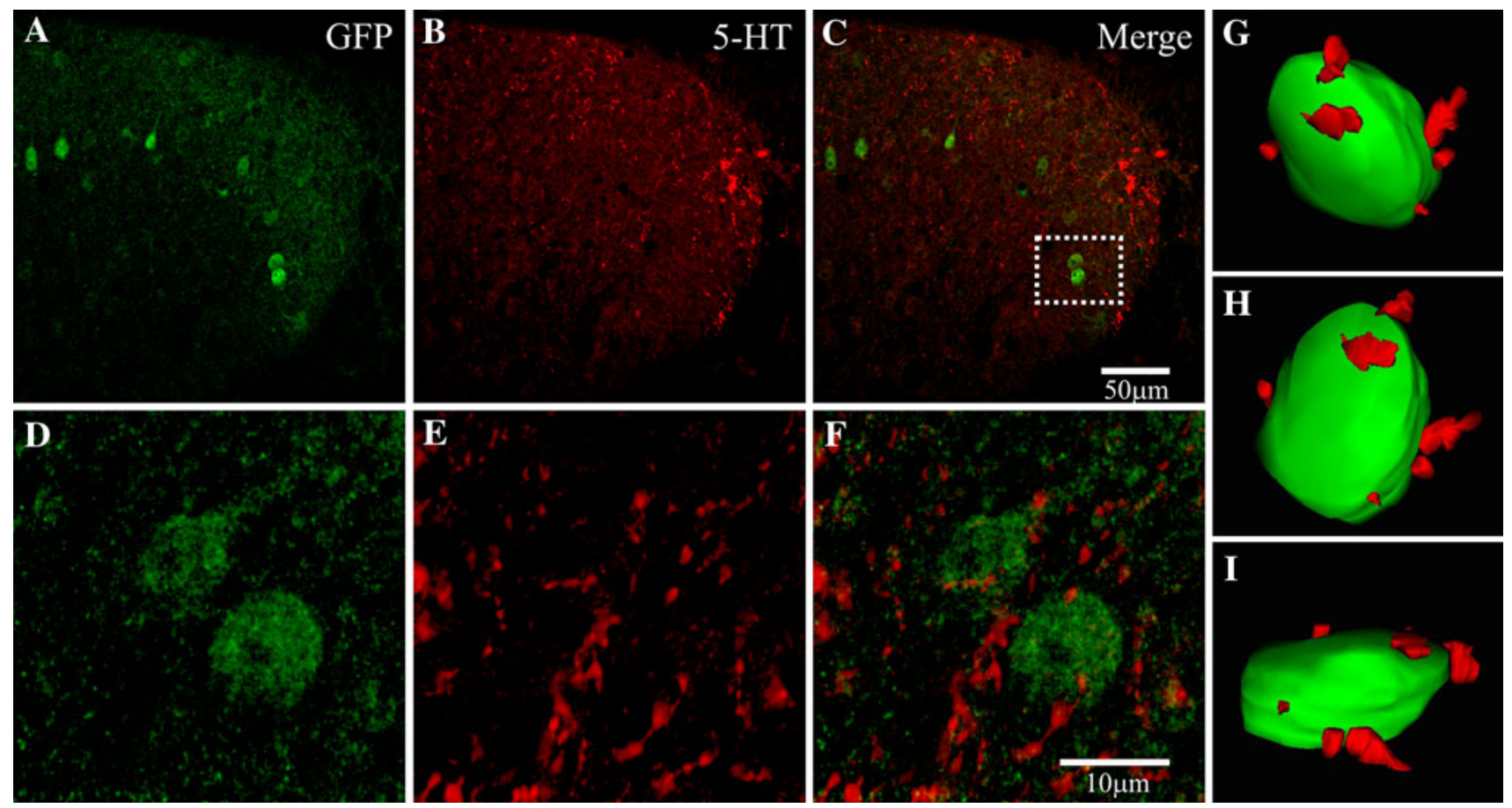

Fig. 5 Cx45-eGFP cells receive close appositions from 5-HT positive terminals. Cx45-eGFP can be seen throughout laminae IIIII (a) and staining for putative 5HT terminals can also be observed throughout the DH (b). d-f High powered magnification of box $A$ in c displayed two example Cx45-eGFP cells surrounded by a high

eGFP, since it is possible that low levels of expression cannot be visualised even after immunohistochemical amplification. However, similar issues including differentiation from background may also arise with low mRNA levels in in situ hybridisation or low protein levels in immunohistochemistry. Nevertheless, the eGFP reporter mouse facilitates dual immunohistochemical labelling, which is rarely possible under the stringent conditions necessary to detect mRNA using in situ hybridisation. We have therefore utilised this advantage to localise $\mathrm{Cx} 45$ eGFP in the spinal cord and to examine the neurochemistry of the eGFP expressing cells in the dorsal horn.

\section{Cx45 expression in the spinal cord and dorsal horn}

Significant numbers of Cx45-eGFP cells were distributed rostrocaudally along the entire spinal cord in cervical, thoracic, lumbar and sacral segments. Cx45-eGFP neurones predominantly lay within superficial dorsal horn, an area crucial for nociceptive sensory processing. The highest concentration of $\mathrm{Cx} 45$-eGFP cells was in laminae II-III with fewer cells scattered across lamina I. Cx45-eGFP cells were absent from deeper laminae (IV-VI) which process mainly low threshold non-noxious sensory afferent inputs (Willis and Coggeshall 2004). A strong association of Cx45-eGFP cells in the dorsal horn with the neuronal density of putatively 5-HT terminals. g-i A reconstructed 3D model example illustrating the density of 5-HT projections surrounding the cell soma and potential sites of contact. Colour images are shown online

marker NeuN but not the glial marker GFAP confirms earlier data derived from $\mathrm{Cx} 45$-reporter mice, where $\mathrm{Cx} 45$ expression was unequivocally associated with neurones rather than glia (Maxeiner et al. 2003). In contrast to previous immunocytochemical data for $\mathrm{Cx} 45$ and spinal cord (Pastor et al. 1998), we did not observe significant levels of Cx45-eGFP within white matter oligodendrocytes.

\section{Co-localisation of $\mathrm{Cx} 45-\mathrm{eGFP}$ cells with $\mathrm{CB}$ and CR}

Calcium-binding proteins such as $\mathrm{CB}, \mathrm{CR}$ and $\mathrm{PV}$ are abundant in rat spinal dorsal horn and display distinct patterns of expression (Ren and Ruda 1994). In rat superficial dorsal horn, CB-containing cells are distributed across I-III but are especially concentrated within I/II whilst PV-containing cells are concentrated within the inner portion of lamina II as well as laminae III (Yoshida et al. 1990). CR is expressed in neurones of the rat dorsal horn, particularly those localized to laminae II, and more intensely within laminae V and VI (Ren and Ruda 1994). In this study, characterization of CBP expression profiles in mouse dorsal horn revealed close similarities to rat as previously documented (Sasaki et al. 2006), whereby CB and CR expression was observed within laminae I-II, whilst PV intensely stains the inner part of lamina II. A high degree of co-localisation of $\mathrm{Cx} 45$-eGFP cells with $\mathrm{CB}$ 
and to a lesser extent with CR but not with PV was evident. The presence of specific CBPs in distinct neuronal populations has prompted the suggestion that CBPs may define specific subsets of interneurones (Antal et al. 1991). Thus, $\mathrm{CB}$ is present in glutamatergic neurones whilst PV neurones may characterize a subpopulation of GABAergic interneurones (Ren and Ruda 1994; Todd and Spike 1993; Albuquerque et al. 1999). Based on detected CBP expression profiles, it may be inferred that $\mathrm{Cx} 45-\mathrm{eGFP}$ cells in the mouse dorsal horn are not GABAergic and have an excitatory phenotype. This proposal is reinforced by the lack of co-localisation of Cx45-eGFP cells with GAD-67, a GABA-synthesizing enzyme that is expressed in GABAergic interneurones (Heinke et al. 2004).

In superficial dorsal horn, CB but not PV has been colocalized with neuropeptides such as substance $\mathrm{P}$ or enkephalin (Yoshida et al. 1990). Both these neuropeptides operate through G-protein-coupled receptor signalling mechanisms that can impact on intracellular calcium levels and play key roles in nociceptive processing. $\mathrm{CB}$ is reportedly present in projection neurones within lamina I that could either be spinothalamic or spinomesencephalic (Yoshida et al. 1990; Menetrey et al. 1992). However, immunolabelling for the $\mathrm{NK}_{1} \mathrm{R}$ receptor, which is present in neurones within lamina $I$ that constitute part of the spinothalamic tract (Al-Khater et al. 2008), revealed no colocalisation with the $\mathrm{Cx} 45$-eGFP cells. Nevertheless, some of the CB-containing cells in laminae II-III cannot be ruled out as also projecting to these brain regions (Yoshida et al. 1990).

Cx45-eGFP cells putatively receive nociceptive non-peptidergic sensory afferent inputs

Two populations of nociceptors that terminate within superficial dorsal horn have been characterized and consist of an IB4-positive non-peptidergic group that projects to the inner layer of lamina II and a CGRP-positive peptidergic group that projects more superficially to lamina I and the outer layer of lamina II (Hunt and Mantyh 2001; Snider and McMahon 1998). There is sparse data on the identity of neurones second order to these groups of sensory afferents, although it is known that peptidergic afferents containing substance $\mathrm{P}$ innervate $\mathrm{NK}_{1} \mathrm{R}$ immunoreactive projection neurones in lamina I and those with cell bodies in lamina III or IV (Naim et al. 1997; Todd et al. 2002). In this study, widespread projections of nonpeptidergic, presumed nociceptive, IB4-positive afferents were pre-dominantly localized to lamina I and the inner layer of lamina II, with some fibres observed in lamina III. As Cx45-eGFP cells were distributed across laminae I-III, it was observed that all $\mathrm{Cx} 45$-eGFP cell bodies within laminae I-II were closely apposed by IB4-positive afferents and most of the Cx45-eGFP cells within lamina III were also in close proximity to IB4-positive afferents. No evidence was obtained for significant putative innervation by the CGRP-positive peptidergic afferent group onto Cx45-eGFP somata although due to the low level of dendritic eGFP expression we cannot eliminate the possibility of undetected dendritic innervation. Thus IB4 nociceptors may provide a significant source of synaptic input to $\mathrm{Cx} 45$-eGFP cells in the DH but this requires further validation. Although both groups of nociceptors are physiologically classified as polymodal, i.e. respond to both mechanical and thermal stimuli it has been suggested that IB4 fibres co-expressing the G-protein-coupled receptor 'Mrgprd' are selectively required for painful mechanosensation (Cavanaugh et al. 2009; Zylka et al. 2005). In rat dorsal horn, IB4 afferents terminate centrally within glomeruli (Gerke and Plenderleith 2004), typically synapsing within a complex of dendrites and axons surrounded by glia that are believed to provide for pre- and postsynaptic modulation of sensory inputs. Our data for mouse dorsal horn are suggestive of putative contacts between IB4 afferents and Cx45-eGFP neuronal somata rather than within glomeruli but additional electron microscopy will be required to validate this finding and determine whether synapses are present.

Cx45-eGFP cells did not co-localize with $\mathrm{PKC} \gamma$, a signalling molecule that has been demonstrated to contribute towards the induction and maintenance of persistent pain following injury. PKC $\gamma$ cells within lamina II in the mouse receive predominantly myelinated afferent inputs (Neumann et al. 2008). As Cx45-eGFP cells do not co-localize $\mathrm{PKC} \gamma$, this finding complements the proposal that $\mathrm{Cx} 45$ eGFP cells receive putative non-peptidergic inputs. Additionally, Cx45-eGFP cells did not co-localize with $\mathrm{NK}_{1} \mathrm{R}$, MOR, nNOS or ChAT. With the exception of ChAT, all these markers are observed in cells found within either laminae I and/or II and have been documented to be involved with nociceptive processing. ChAT could be observed within lamina III and $\mathrm{X}$, and as cholinergic neurones within lamina III have been shown to frequently co-localize GABA (Spike et al. 1993) this finding ties in with the observed lack of co-localization of GAD-67 with Cx45-eGFP cells.

Cx45-eGFP cells are innervated by 5-HT-, but not TH- or OT-immunopositive fibres

The superficial dorsal horn receives extrinsic innervation from diverse supraspinal regions via serotoninergic, oxytocinergic, catecholaminergic/dopaminergic descending pathways (VanderHorst and Ulfhake 2006). Immunoreactivity for OT in dorsal horn mainly originates from direct paraventricular hypothalamic projections to the spinal cord 
(Condes-Lara et al. 2007) and in rat OT-immunoreactivity is predominantly found within laminae I-II (Reiter et al. 1994). TH-immunoreactivity may be representative of noradrenergic, adrenergic and/or dopaminergic fibres that originate in the mesopontine tegmentum especially the locus coeruleus and in the mouse dorsal horn TH-immunoreactivity is most concentrated within laminae II-III (VanderHorst and Ulfhake 2006). In this study, no clear relationship was established between Cx45-eGFP cells and OT-IR or TH-IR terminals. On the other hand, close appositions were detected between 5-HT terminals and Cx45-eGFP cells in laminae I-II. Serotoninergic innervation within the spinal cord is widespread and many 5-HTIR profiles are found within the inner layer of lamina II with fewer in laminae III/IV (Steinbusch 1981; Marlier et al. 1991). These data are suggestive of innervation of Cx45-eGFP cells via descending monoaminergic control systems that have been described as either pro- or antinociceptive depending on the class of 5-HT receptors activated (Suzuki et al. 2004).

Functional significance of $\mathrm{Cx} 45$-eGFP cells in murine dorsal horn nociceptive circuitry

The physiological significance of localization of Cx45 within the superficial dorsal horn or whether $\mathrm{Cx} 45$ is assembled into functional gap junctions remains to be resolved. In fact, $\mathrm{Cx} 45$ is competent to form heterotypic channels with several other $\mathrm{Cx}$ proteins including neuronal Cx36 (Li et al. 2008) and glial Cx43 (Rackauskas et al. 2007). Data from cell lines have demonstrated that $\mathrm{Cx} 45$ can form either homotypic $(\mathrm{Cx} 45 / \mathrm{Cx} 45)$ or heterotypic (Cx45/Cx43) gap junctions that are highly sensitive to the transjunctional voltage (Bukauskas et al. 2002). Previously, using immature rat dorsal horn in vitro, we demonstrated a contribution of gap junctions associated with either neurones or glia in rhythmic behaviour generated by neuronal networks embedded within substantia gelatinosa (Asghar et al. 2005; Chapman et al. 2009). Emerging data reveal a potential contribution of gap junctions to chronic pain states. For example, Cx37 increased in sciatic nerve after injury and this change correlated with behavioural hyperalgesia (Lin et al. 2002). Gap junction-coupled networks may exacerbate neuropathic spreading pain sensations (Spataro et al. 2004) and contribute to abnormal nociceptive behaviours and hyperalgesia induced by inflammation (Qin et al. 2006). In conclusion, it is possible that the dorsal horn expresses $\mathrm{Cx}$ protein subtypes that, under certain conditions, are incorporated into functional gap junctions operating within coupled neuronalglial networks relevant to somatosensory encoding and nociception.
Acknowledgments This work was supported by The Wellcome Trust and Biotechnology and Biological Sciences Research Council (BBRSC). Work in the Bonn laboratory was supported by a grant of the German Research Association (Wi270/29-1) to K.W. We would like to thank Drs. Ian Edwards and Deborah Conte for their help with the immunohistological techniques and analyses. We are grateful to the Allen Brain Atlas Resource (Allen Institute for Brain Science: http://www.brain-map.org) from which Fig. $1 \mathrm{~b}$ and $\mathrm{d}$ are derived.

Open Access This article is distributed under the terms of the Creative Commons Attribution License which permits any use, distribution, and reproduction in any medium, provided the original author(s) and the source are credited.

\section{References}

Al-Khater KM, Kerr R, Todd AJ (2008) A quantitative study of spinothalamic neurons in laminae I, III, and IV in lumbar and cervical segments of the rat spinal cord. J Comp Neurol 511:1-18

Albuquerque C, Lee CJ, Jackson AC, MacDermott AB (1999) Subpopulations of GABAergic and non-GABAergic rat dorsal horn neurons express $\mathrm{Ca}^{2+}$-permeable AMPA receptors. Eur J Neurosci 11:2758-2766

Antal M, Polgar E, Chalmers J, Minson JB, Llewellyn-Smith I, Heizmann CW, Somogyi P (1991) Different populations of parvalbumin- and calbindin-D28k-immunoreactive neurons contain GABA and accumulate $3 \mathrm{H}$-D-aspartate in the dorsal horn of the rat spinal cord. J Comp Neurol 314:114-124

Arvidsson U, Riedl M, Chakrabarti S, Lee JH, Nakano AH, Dado RJ, Loh HH, Law PY, Wessendorf MW, Elde R (1995) Distribution and targeting of a mu-opioid receptor (MOR1) in brain and spinal cord. J Neurosci 15:3328-3341

Asghar AU, Cilia La Corte PF, LeBeau FE, Al DM, Reilly SC, Buhl EH, Whittington MA, King AE (2005) Oscillatory activity within rat substantia gelatinosa in vitro: a role for chemical and electrical neurotransmission. J Physiol 562:183-198

Brumovsky P, Villar MJ, Hokfelt T (2006) Tyrosine hydroxylase is expressed in a subpopulation of small dorsal root ganglion neurons in the adult mouse. Exp Neurol 200:153-165

Bukauskas FF, Angele AB, Verselis VK, Bennett MV (2002) Coupling asymmetry of heterotypic connexin 45/connexin 43-EGFP gap junctions: properties of fast and slow gating mechanisms. Proc Natl Acad Sci USA 99:7113-7118

Cavanaugh DJ, Lee H, Lo L, Shields SD, Zylka MJ, Basbaum AI, Anderson DJ (2009) Distinct subsets of unmyelinated primary sensory fibers mediate behavioral responses to noxious thermal and mechanical stimuli. Proc Natl Acad Sci USA 106:90759080

Celio MR, Baier W, Scharer L, de Viragh PA, Gerday C (1988) Monoclonal antibodies directed against the calcium binding protein parvalbumin. Cell Calcium 9:81-86

Chapman RJ, Cilia La Corte PF, Asghar AU, King AE (2009) Network-based activity induced by 4-aminopyridine in rat dorsal horn in vitro is mediated by both chemical and electrical synapses. J Physiol 587:2499-2510

Condes-Lara M, Martinez-Lorenzana G, Rojas-Piloni G, RodriguezJimenez J (2007) Branched oxytocinergic innervations from the paraventricular hypothalamic nuclei to superficial layers in the spinal cord. Brain Res 1160:20-29

Condorelli DF, Parenti R, Spinella F, Trovato SA, Belluardo N, Cardile V, Cicirata F (1998) Cloning of a new gap junction gene 
(Cx36) highly expressed in mammalian brain neurons. Eur $\mathrm{J}$ Neurosci 10:1202-1208

Dedek K, Breuninger T, de Sevilla Muller LP, Maxeiner S, Schultz K, Janssen-Bienhold U, Willecke K, Euler T, Weiler R (2009) A novel type of interplexiform amacrine cell in the mouse retina. Eur J Neurosci 30:217-228

Dermietzel R (1998) Diversification of gap junction proteins (connexins) in the central nervous system and the concept of functional compartments. Cell Biol Int 22:719-730

Fiala JC (2005) Reconstruct: a free editor for serial section microscopy. J Microsc 218:52-61

Fong AY, Stornetta RL, Foley CM, Potts JT (2005) Immunohistochemical localization of GAD67-expressing neurons and processes in the rat brainstem: subregional distribution in the nucleus tractus solitarius. J Comp Neurol 493:274-290

Gao YJ, Zhang L, Samad OA, Suter MR, Yasuhiko K, Xu ZZ, Park JY, Lind AL, Ma Q, Ji RR (2009) JNK-induced MCP-1 production in spinal cord astrocytes contributes to central sensitization and neuropathic pain. J Neurosci 29:4096-4108

Gensat (2011) The gene expression nervous system atlas (GENSAT) project, NINDS Contracts N01NS02331 \& HHSN271200723 $701 \mathrm{C}$ to The Rockefeller University (New York, NY)

Gerke MB, Plenderleith MB (2004) Ultrastructural analysis of the central terminals of primary sensory neurones labelled by transganglionic transport of bandeiraea simplicifolia I-isolectin B4. Neuroscience 127:165-175

Heinke B, Ruscheweyh R, Forsthuber L, Wunderbaldinger G, Sandkuhler J (2004) Physiological, neurochemical and morphological properties of a subgroup of GABAergic spinal lamina II neurones identified by expression of green fluorescent protein in mice. J Physiol 560:249-266

Hombach S, Janssen-Bienhold U, Sohl G, Schubert T, Bussow H, Ott $\mathrm{T}$, Weiler R, Willecke K (2004) Functional expression of connexin57 in horizontal cells of the mouse retina. Eur $\mathrm{J}$ Neurosci 19:2633-2640

Hunt SP, Mantyh PW (2001) The molecular dynamics of pain control. Nat Rev Neurosci 2:83-91

Izzo PN, Deuchars J, Spyer KM (1993) Localization of cardiac vagal preganglionic motoneurones in the rat: immunocytochemical evidence of synaptic inputs containing 5-hydroxytryptamine. J Comp Neurol 327:572-583

Lan L, Yuan H, Duan L, Cao R, Gao B, Shen J, Xiong Y, Chen LW, Rao ZR (2007) Blocking the glial function suppresses subcutaneous formalin-induced nociceptive behavior in the rat. Neurosci Res 57:112-119

Li X, Kamasawa N, Ciolofan C, Olson CO, Lu S, Davidson KG, Yasumura T, Shigemoto R, Rash JE, Nagy JI (2008) Connexin45-containing neuronal gap junctions in rodent retina also contain connexin36 in both apposing hemiplaques, forming bihomotypic gap junctions, with scaffolding contributed by zonula occludens-1. J Neurosci 28:9769-9789

Lin SH, Lu CY, Muhammad R, Chou WY, Lin FC, Wu PC, Lin CR, Yang LC (2002) Induction of connexin 37 expression in a rat model of neuropathic pain. Brain Res Mol Brain Res 99:134-140

Ma W, Eisenach JC (2007) Neuronal nitric oxide synthase is upregulated in a subset of primary sensory afferents after nerve injury which are necessary for analgesia from alpha2-adrenoceptor stimulation. Brain Res 1127:52-58

Maihofner C, Tegeder I, Euchenhofer C, deWitt D, Brune K, Bang R, Neuhuber W, Geisslinger G (2000) Localization and regulation of cyclo-oxygenase- 1 and -2 and neuronal nitric oxide synthase in mouse spinal cord. Neuroscience 101:1093-1108

Malmberg AB, Chen C, Tonegawa S, Basbaum AI (1997) Preserved acute pain and reduced neuropathic pain in mice lacking PKCgamma. Science 278:279-283
Marlier L, Sandillon F, Poulat P, Rajaofetra N, Geffard M, Privat A (1991) Serotonergic innervation of the dorsal horn of rat spinal cord: light and electron microscopic immunocytochemical study. J Neurocytol 20:310-322

Maxeiner S, Dedek K, Janssen-Bienhold U, Ammermuller J, Brune H, Kirsch T, Pieper M, Degen J, Kruger O, Willecke K, Weiler R (2005) Deletion of connexin45 in mouse retinal neurons disrupts the rod/cone signaling pathway between AII amacrine and ON cone bipolar cells and leads to impaired visual transmission. J Neurosci 25:566-576

Maxeiner S, Kruger O, Schilling K, Traub O, Urschel S, Willecke K (2003) Spatiotemporal transcription of connexin 45 during brain development results in neuronal expression in adult mice. Neuroscience 119:689-700

Menetrey D, De PJ, Thomasset M, Baimbridge KG (1992) CalbindinD28K (CaBP28k)-like immunoreactivity in ascending projections. Eur J Neurosci 4:70-76

Milligan CJ, Edwards IJ, Deuchars J (2006) HCN1 ion channel immunoreactivity in spinal cord and medulla oblongata. Brain Res 1081:79-91

Mullen RJ, Buck CR, Smith AM (1992) NeuN, a neuronal specific nuclear protein in vertebrates. Development 116:201-211

Nagy JI, Rash JE (2000) Connexins and gap junctions of astrocytes and oligodendrocytes in the CNS. Brain Res Brain Res Rev 32:29-44

Naim M, Spike RC, Watt C, Shehab SA, Todd AJ (1997) Cells in laminae III and IV of the rat spinal cord that possess the neurokinin-1 receptor and have dorsally directed dendrites receive a major synaptic input from tachykinin-containing primary afferents. J Neurosci 17:5536-5548

Neumann S, Braz JM, Skinner K, Llewellyn-Smith IJ, Basbaum AI (2008) Innocuous, not noxious, input activates PKCgamma interneurons of the spinal dorsal horn via myelinated afferent fibers. J Neurosci 28:7936-7944

Ochalski PA, Frankenstein UN, Hertzberg EL, Nagy JI (1997) Connexin-43 in rat spinal cord: localization in astrocytes and identification of heterotypic astro-oligodendrocytic gap junctions. Neuroscience 76:931-945

Pastor A, Kremer M, Moller T, Kettenmann H, Dermietzel R (1998) Dye coupling between spinal cord oligodendrocytes: differences in coupling efficiency between gray and white matter. Glia 24:108-120

Qin M, Wang JJ, Cao R, Zhang H, Duan L, Gao B, Xiong YF, Chen LW, Rao ZR (2006) The lumbar spinal cord glial cells actively modulate subcutaneous formalin induced hyperalgesia in the rat. Neurosci Res 55:442-450

Rackauskas M, Kreuzberg MM, Pranevicius M, Willecke K, Verselis VK, Bukauskas FF (2007) Gating properties of heterotypic gap junction channels formed of connexins 40,43 , and 45 . Biophys $\mathbf{J}$ 92:1952-1965

Rash JE, Dillman RK, Bilhartz BL, Duffy HS, Whalen LR, Yasumura T (1996) Mixed synapses discovered and mapped throughout mammalian spinal cord. Proc Natl Acad Sci USA 93:4235-4239

Rash JE, Staines WA, Yasumura T, Patel D, Furman CS, Stelmack GL, Nagy JI (2000) Immunogold evidence that neuronal gap junctions in adult rat brain and spinal cord contain connexin-36 but not connexin-32 or connexin-43. Proc Natl Acad Sci USA 97:7573-7578

Reiter MK, Kremarik P, Freund-Mercier MJ, Stoeckel ME, Desaulles E, Feltz P (1994) Localization of oxytocin binding sites in the thoracic and upper lumbar spinal cord of the adult and postnatal rat: a histoautoradiographic study. Eur J Neurosci 6:98-104

Ren K, Ruda MA (1994) A comparative study of the calcium-binding proteins calbindin-D28K, calretinin, calmodulin and parvalbumin in the rat spinal cord. Brain Res Brain Res Rev 19:163-179 
Robinson DA, Wei F, Wang GD, Li P, Kim SJ, Vogt SK, Muglia LJ, Zhuo M (2002) Oxytocin mediates stress-induced analgesia in adult mice. J Physiol 540:593-606

Ruda MA, Besse D, Inagaki S, DeLeon M, Ren K (1994) Nitric oxide expression and regulation in the dorsal root ganglion and spinal cord. Ann N Y Acad Sci 738:181-190

Sasaki S, Warita H, Komori T, Murakami T, Abe K, Iwata M (2006) Parvalbumin and calbindin D-28k immunoreactivity in transgenic mice with a G93A mutant SOD1 gene. Brain Res 1083:196-203

Schwaller B, Buchwald P, Blumcke I, Celio MR, Hunziker W (1993) Characterization of a polyclonal antiserum against the purified human recombinant calcium binding protein calretinin. Cell Calcium 14:639-648

Schwaller B, Dick J, Dhoot G, Carroll S, Vrbova G, Nicotera P, Pette D, Wyss A, Bluethmann H, Hunziker W, Celio MR (1999) Prolonged contraction-relaxation cycle of fast-twitch muscles in parvalbumin knockout mice. Am J Physiol 276:C395-C403

Schubert T, Maxeiner S, Kruger O, Willecke K, Weiler R (2005) Connexin 45 mediates gap junctional coupling of bistratified ganglion cells in the mouse retina. J Comp Neurol 490:29-39

Snider WD, McMahon SB (1998) Tackling pain at the source: new ideas about nociceptors. Neuron 20:629-632

Sohl G, Maxeiner S, Willecke K (2005) Expression and functions of neuronal gap junctions. Nat Rev Neurosci 6:191-200

Sohl G, Willecke K (2003) An update on connexin genes and their nomenclature in mouse and man. Cell Commun Adhes 10:173-180

Spataro LE, Sloane EM, Milligan ED, Wieseler-Frank J, Schoeniger D, Jekich BM, Barrientos RM, Maier SF, Watkins LR (2004) Spinal gap junctions: potential involvement in pain facilitation. J Pain 5:392-405

Spike RC, Todd AJ, Johnston HM (1993) Coexistence of NADPH diaphorase with GABA, glycine, and acetylcholine in rat spinal cord. J Comp Neurol 335:320-333

Steinbusch HW (1981) Distribution of serotonin-immunoreactivity in the central nervous system of the rat-cell bodies and terminals. Neuroscience 6:557-618

Suzuki R, Rygh LJ, Dickenson AH (2004) Bad news from the brain: descending 5-HT pathways that control spinal pain processing. Trends Pharmacol Sci 25:613-617

Teubner B, Odermatt B, Guldenagel M, Sohl G, Degen J, Bukauskas F, Kronengold J, Verselis VK, Jung YT, Kozak CA, Schilling K, Willecke K (2001) Functional expression of the new gap junction gene connexin 47 transcribed in mouse brain and spinal cord neurons. J Neurosci 21:1117-1126
Theis M, Magin TM, Plum A, Willecke K (2000) General or cell type-specific deletion and replacement of connexin-coding DNA in the mouse. Methods 20:205-218

Theis M, Sohl G, Eiberger J, Willecke K (2005) Emerging complexities in identity and function of glial connexins. Trends Neurosci 28:188-195

Todd AJ, Spike RC (1993) The localization of classical transmitters and neuropeptides within neurons in laminae I-III of the mammalian spinal dorsal horn. Prog Neurobiol 41:609-645

Todd AJ, Puskar Z, Spike RC, Hughes C, Watt C, Forrest L (2002) Projection neurons in lamina I of rat spinal cord with the neurokinin 1 receptor are selectively innervated by substance p-containing afferents and respond to noxious stimulation. J Neurosci 22:4103-4113

Van Der Giessen RS, Maxeiner S, French PJ, Willecke K, de Zeeuw CI (2006) Spatiotemporal distribution of Connexin 45 in the olivocerebellar system. J Comp Neurol 495:173-184

VanderHorst VG, Ulfhake B (2006) The organization of the brainstem and spinal cord of the mouse: relationships between monoaminergic, cholinergic, and spinal projection systems. J Chem Neuroanat 31:2-36

Vervaeke K, Lorincz A, Gleeson P, Farinella M, Nusser Z, Silver RA (2010) Rapid desynchronization of an electrically coupled interneuron network with sparse excitatory synaptic input. Neuron 67:435-451

Vigna SR, Bowden JJ, McDonald DM, Fisher J, Okamoto A, McVey DC, Payan DG, Bunnett NW (1994) Characterization of antibodies to the rat substance $\mathrm{P}(\mathrm{NK}-1)$ receptor and to a chimeric substance $\mathrm{P}$ receptor expressed in mammalian cells. J Neurosci 14:834-845

Watson C, Paxinos G, Kayalioglu G, Heise C (2009) Atlas of the mouse spinal cord. In: Watson C, Paxinos G, Kayalioglu G (eds) The spinal cord, Academic Press, San Diego, pp 308-379

Willis WD, Coggeshall RE (2004) Sensory mechanisms of the spinal cord: primary afferent neurons and the spinal dorsal horn, 3rd edn. Springer, Berlin, pp 789-876

Yoshida S, Senba E, Kubota Y, Hagihira S, Yoshiya I, Emson PC, Tohyama M (1990) Calcium-binding proteins calbindin and parvalbumin in the superficial dorsal horn of the rat spinal cord. Neuroscience 37:839-848

Zylka MJ, Rice FL, Anderson DJ (2005) Topographically distinct epidermal nociceptive circuits revealed by axonal tracers targeted to Mrgprd. Neuron 45:17-25 